\title{
MODEL TURBIN ANGIN AIRFOIL NACA 4418 TERHADAP VARIASI BUKAAN SUDUT SUDU PADA KECEPATAN ANGIN BERBEDA
}

\author{
Yusuf Dewantoro Herlambang ${ }^{1}$, Budhi Prasetiyo ${ }^{1}$, Supriyo ${ }^{1}$, Wahyono ${ }^{1}$, \\ Teguh Harijono Mulud ${ }^{1}$ \\ ${ }^{1}$ Program Studi Teknik Konversi Energi, Jurusan Teknik Mesin, \\ Politeknik Negeri Semarang \\ Jl. Prof. Sudarto, SH Tembalang Semarang 50275 \\ E-mail : masyusufdh@polines.ac.id
}

\begin{abstract}
This study has investigated Vertical Axis Wind Turbine Aerofoil NACA 4418 has a rotor diameter of $560 \mathrm{~mm}$, a blade length of $800 \mathrm{~mm}$, the number of 3 blades and the blade made of fiberglass. Subsequently, we analyzes the characteristics of the 3-blade vertical rotor wind turbine at different wind speeds of $5 \mathrm{~m} / \mathrm{s}, 6 \mathrm{~m} / \mathrm{s}, 7 \mathrm{~m} / \mathrm{s}, 8 \mathrm{~m} / \mathrm{s}$ and $9 \mathrm{~m} / \mathrm{s}$ with 5 wind turbine models with blade pitch angle $0^{\circ}, 10^{\circ}, 20^{\circ}, 30^{\circ}$, and $40^{\circ}$. The results of this study obtained by the optimum Tip Speed Ratio (TSR) of 1.7 with blade pitch angle $10^{\circ}$ at rotation speed of 321 rpm and wind speed $5.42 \mathrm{~m} / \mathrm{s}$. The optimum mechanical power of $19.4 \mathrm{~W}$ was obtained at a blade pitch angle $20^{\circ}$ with a turbine speed 381 at wind speed turbine of $6.4 \mathrm{~m} / \mathrm{s}$. While the optimum Coefficient of Power (CP) of 0,202 generated by the turbine with a blade pitch angle $10^{\circ}$ at $198 \mathrm{rpm}$ turbine speed, and $8.5 \mathrm{~W}$ that obtained mechanical power with a variable speed test of $5.42 \mathrm{~m} / \mathrm{s}$.
\end{abstract}

Keywords: VAWT wind turbine, wind speed, blade angle, tip speed ratio, coefficient of power

\begin{abstract}
Abstrak
Penelitian ini mengkaji Turbin Angin Sumbu Vertikal (Vertical Axis Wind Turbine) Aerofoil NACA 4418 yang memiliki diameter rotor $560 \mathrm{~mm}$, panjang sudu $800 \mathrm{~mm}$, jumlah sudu 3 buah, serta bahan sudu terbuat dari fiberglass. Selanjutnya menganalis karakteristik turbin angin rotor vertikal 3 -sudu tersebut pada kecepatan angin berbeda $5 \mathrm{~m} / \mathrm{s}, 6 \mathrm{~m} / \mathrm{s}, 7 \mathrm{~m} / \mathrm{s}, 8 \mathrm{~m} / \mathrm{s}$, dan $9 \mathrm{~m} / \mathrm{s}$ dengan 5 buah model turbin angin dengan bukaan sudut sudu (blade pitch angle) bervariasi yaitu $0^{\circ}, 10^{\circ}, 20^{\circ}, 30^{\circ}$, dan $40^{\circ}$. Hasil pengujian turbin angin diperoleh rasio kecepatan sudu (Tip Speed Ratio) yang optimum sebesar 1,7 pada sudut sudu $10^{\circ}$ dengan putaran turbin $321 \mathrm{rpm}$ dan kecepatan angin $5,42 \mathrm{~m} / \mathrm{s}$. Daya mekanik optimum yang diperoleh adalah $19,4 \mathrm{~W}$ pada bukaan sudut sudu sebesar $20^{\circ}$ dengan putaran turbin 381 serta kecepatan angin $6,4 \mathrm{~m} / \mathrm{s}$. Turbin menghasilkan koesifien daya (Coefficient of Power) optimum yang dihasilkan sebesar 0,202 dengan bukaan sudut sudu sebesar $10^{0}$ dan putaran turbin $198 \mathrm{rpm}$, dan daya mekanik yang dihasilkan 8,5 Watt pada variabel pengujian kecepatan sebesar $5,42 \mathrm{~m} / \mathrm{s}$.
\end{abstract}

Kata Kunci: Turbin angin VAWT 4418, kecepatan angin, bukaan sudut sudu, rasio kecepatan sudu, koefisien daya

\section{PENDAHULUAN}

Program percepatan pembangunan pembangkit baru tersebut bertujuan untuk meningkatkan rasio elektrifikasi dari sebelumnya $87,4 \%$ pada tahun 2015 menjadi sekitar 97\% pada tahun 2019. Pemerintah dalam hal ini PLN memiliki komitmen untuk meningkatkan rasio elektrifikasi di wilayah perdesaan, daerah terpencil, dan pulau terluar Indonesia. Rasio elektrifikasi adalah perbandingan jumlah penduduk Indonesia yang sudah menikmati fasilitas listrik dengan jumlah total penduduk Indonesia. Perpres No. 5 tahun 2006 tentang Kebijakan Energi Nasional disebutkan bahwa kontribusi pengembangan energi baru terbarukan (EBT) dalam bauran energi primer nasional sampai dengan tahun 2015 yakni sebesar 17\% dengan komposisi panas bumi 5\%, air, surya, angin, biomassa, dan nuklir sebesar 5\%, bahan bakar nabati (biodiesel dan bioethanol) sebesar 5\%, serta

97 | Jurnal Integrasi | Vol.11 No.2, October 2019, 97-102 | e-ISSN: 2548-9828 
batu bara yang dicairkan sebesar 2\%. Diharapkan sampai dengan tahun 2025 bauran energy primer nasional meningkat menjadi $23 \%$. Berdasarkan data diatas, Indonesia akan mengalami krisis energi, dikarenakan semua jenis energi Indonesia akan habis dalam kurun waktu 90 tahun (AWEA/BWEA, 2004). Salah satu penerapan turbin angin kapasitas 75 MW di Desa Mattirotasi Kabupaten Sidrap Sulawesi Selatan. Sejumlah 30 Wind Turbine Generator (WTG) yang mampu mengaliri listrik kepada 70.000 rumah. Penelitian terkait pemanfaatan energi baru terbarukan seperti pembangkit tenaga surya, air, mikrofluida fuel cell dan pembangkit tenaga angina sudah dilakukan oleh Herlambang (2010, 2016, 2017). Prinsip kerja dari turbin angin VAWT dengan memanfaatkan angin yang berasal dari blower kemudian angin ditangkap oleh sudu-sudu turbin, sehingga timbul energi mekanik yang berasal dari poros turbin selanjutnya dikonversikan menjadi energi listrik yang berasal dari generator (Herlambang 2016, 2017; Soelaiman, 2010; Hermawan, 2010). Energi kinetik dari massa udara $\mathrm{m}$ yang bergerak pada kecepatan v (Leysen, 1983 dan Hau, 2006):

$\mathrm{P}_{\text {kin }}=\frac{1}{2} \dot{m} \cdot \mathrm{v}^{2}(\mathbf{1})$

Mengacu pada luas potongan melintang tertentu A, yang dilewati lintasan udara pada kecepatan $\mathrm{v}$, volume $\mathrm{V} \cdot$ mengalir melewati unit waktu tertentu, dinamakan aliran volume (volume

flow) dan laju aliran massa disebut $\dot{\boldsymbol{m}}$ adalah (Leysen, 1983):

$$
\dot{m}=\rho \cdot A_{l} \cdot v_{l}(2)
$$

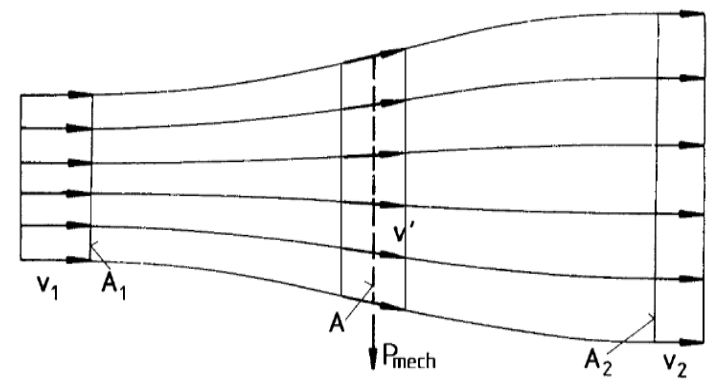

Gambar 1. Kondisi aliran karena pengeluaran energi mekanik dari arus bebas aliran udara, mengacu pada teori dasar momentum.

Energi mekanik yang mana dikeluarkan dari disk-shaped konverter dari aliran udara berkaitan dengan perbedaan daya dari arus udara sebelum dan sesudah konverter (Leysen, 1983):

$\mathrm{P}_{\text {kin }}=\frac{1}{2} \rho \cdot A_{1} \cdot \mathrm{v}_{1}{ }^{3}-\frac{1}{2} \rho \cdot A_{2} \cdot \mathrm{v}_{2}{ }^{3}=\frac{1}{2} \rho\left(A_{1}\right.$

$\left.\cdot \mathrm{v}_{1}^{3}-A_{2} \cdot \mathrm{v}_{2}^{3}\right)(3)$

$\mathrm{v}_{1}$ : kecepatan arus-bebas undelayed, kecepatan angin

$\mathrm{v}_{2}$ : kecepatan aliran dibelakang konverter.

Persamaan kontinuitas yang diperlukan adalah:

$$
\begin{aligned}
& \rho \cdot A_{1} \cdot v_{1}=\rho \cdot A_{2} \cdot v_{2}(\mathbf{4}) \\
& \mathrm{P}=\frac{1}{2} \rho \cdot A_{1} \cdot \mathrm{v}_{1}^{3}\left(\mathrm{v}_{1}^{2}-\mathrm{v}_{2}^{2}\right)(\mathbf{5}) \\
& \text { dimana: }
\end{aligned}
$$

$\rho \quad$ : Massa jenis udara $\left[\mathrm{kg} / \mathrm{m}^{3}\right]$

$A \quad$ : Luas sapuan angin $\left[\mathrm{m}^{2}\right]$

$v \quad:$ Kecepatan angin $[\mathrm{m} / \mathrm{s}]$

indeks 1 merupakan arah masuk; indeks 2 merupakan arah masuk

Menurut Gupta, 2010 dan Grant, 2003 menerangkan bahwa daya akan dapat mencapai maksimum bila kecepatan $\mathrm{v}_{2}$ adalah nol. Akan tetapi, hasil ini tidak bisa dibuat secara fisik sebagaimana dapat diduga, secara fisik hasil berarti terdiri rasio kuantitatip (numerik) tertentu $\mathrm{v}_{2} / \mathrm{v}_{1}$ dimana daya yang dapat dikeluarkan mencapai maksimum dengan $\mathrm{v}_{2} / \mathrm{v}_{1}=16 / 27$ atau $\mathrm{cp}=0,593$.

\section{METODE PENELITIAN}

Tahap pertama adalah pemilihan bahan sudu fiberglas dan perancangan alat dilakukan untuk memperoleh desain dan alternatif yang terbaik. Kegiatan ini dilakukan dengan membuat sketsa gambar sudu rotor angin VAWT beserta mekanismenya, sehingga dihasilkan gambar konstruksi. Besarnya daya turbin ditentukan oleh luas sapuan rotor dan kecepatan angin, setelah diperoleh besarnya daya turbin digunakan untuk menentukan besarnya kapasitas pompa. Perhitungan biaya dilakukan untuk pembuatan alat dan peralatan penunjangnya. Merancang dan membuat turbin angin VAWT airfoil NACA 4418 3-sudu konstruksi sudu curved terdiri dari 3 konstruksi sudu rotor turbin berdiameter $560 \mathrm{~mm}$ tinggi $800 \mathrm{~mm}$ yang dibuat dari campuran serat kayu, ram, resin epoksi dengan perbandingan tertentu. Bagian-bagian sudu turbin diperkuat atau diperkokoh menggunakan besi poros pejal pada sisi lengkung luar dan sisi lengkung dalam sudu. Dalam pembuatan ini melibatkan proses pengerjaan cutting, bending, welding, milling, bubut, dan forming.

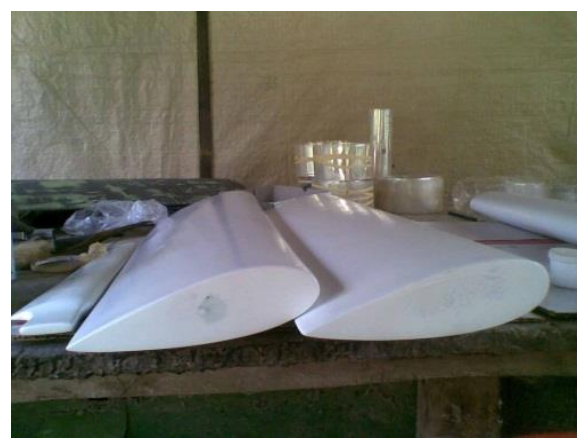

Gambar 2. Cetakan sudu turbin Gorlov NACA 4418

Tahap Pengerjaan dan Perakitan 
Rotor VAWT airfoil NACA 4418 3-sudu terdiri dari rotor turbin, piringan penahan sudu, dan poros. Model rotor VAWT airfoil NACA 4418 3sudu yang dibuat berjumlah 4 buah dengan masingmasing bukaan sudut sudu adalah $5^{\circ}, 10^{\circ}, 15^{\circ}$, dan $20^{\circ}$. Sudu turbin dibuat dari fiberglas (resin polyester, wolver roffing, fiber cloth, serat gelas/mat, pewarna pigmen, katalis). Pemilihan bahan sudu menggunakan cetakan sudu. Diameter rotor VAWT airfoil NACA 4418 3-sudu ini adalah $550 \mathrm{~mm}$ dan tinggi rotor $800 \mathrm{~mm}$. Sudu turbin VAWT airfoil NACA 4418 3-sudu ini terpasang pada suatu piringan/cakram sebagai penyangga sudu.

Tahap Simulasi dan Pengujian

Uji simulasi dilakukan pada turbin dengan unjukkerja terbaik. Simulasi ini menggunakan software ANSYS 14.0 versi mahasiswa. Uji pertama adalah memperoleh desain struktur geometri sudu NACA 4418. Tahap kedua, meshing dengan grid sudu halus untuk mendapatkan kualitas piksel terbaik dan perhitungan yang lebih akurat. Tahap ketiga memberikan gaya statis struktural pada sudu untuk memperoleh beban sudu dan kecepatan angin yang optimal. Sehingga akan diperoleh tegangan maksimum dan minimum di sepanjang sudu turbin. Deformasi elastis pada sudu turbin bisa diperoleh di sepanjang sudu. Faktor keamanan merupakan hal yang sangat penting dalam hal operasional sudu turbin.

Pelaksanaan pengujian, dimana pada tahap ini akan dilakukan pengambilan data. Parameter yang diukur dalam pengujian adalah kecepatan angin $(\mathrm{m} / \mathrm{s})$ yang akan digunakan memutar sudu turbin; putaran poros (rpm), yaitu putaran yang dihasilkan oleh poros turbin setelah sudu turbin dikenai angin dengan kecepatan yang telah ditentukan; torsi $(\mathrm{Nm})$, yaitu besarnya torsi yang dihasilkan dari putaran poros setelah sudu turbin dikenai angin dengan kecepatan yang telah ditentukan; daya turbin (watt), yaitu besarnya daya angin yang mampu dihasilkan oleh turbin angin; Coefficient of Power $C p$, yaitu perbandingan antara daya turbin dengan daya angin.

Pengolahan dan Analisis, Data hasil simulasi aerodinamis dan struktur disesuaikan dengan data pengujian diolah untuk mendapatkan kecepatan angin, putaran poros, torsi, daya turbin, koefisien daya, koefisien torsi. Hasil pengolahan kemudian dipajangkan dalam bentuk grafik karakteristik turbin angin. Unjuk kerja masing-masing turbin tersebut dikaji dan dianalisis. Sehingga akan menghasilkan turbin dengan variasi sudut sudu dan simulasi yang mempunyai unjuk kerja terbaik.

\section{HASIL DAN PEMBAHASAN}

Pengujian simulasi, data hasil uji simulasi aerodinamis turbin dan simulasi struktur desain sudu. Analisis aerodinamis sudu diantaranya adalah analisis tekanan disepanjang permukaan atas dan bawah sudu turbin. Tekanan udara sepanjang permukaan sudu $1,01 \times 10^{5} \mathrm{~Pa}$ yang nilainya konstan sepanjang permukaan sudu. Tekanan udara dibawah permukaan sudu lebih tinggi daripada tekanan pada permukaan. Kontur tekanan sepanjang permukaan sudu dapat digunakan untuk menganalisa tekanan statis, tekanan dinamis dan total tekanan udara disepanjang permukaan sudu.

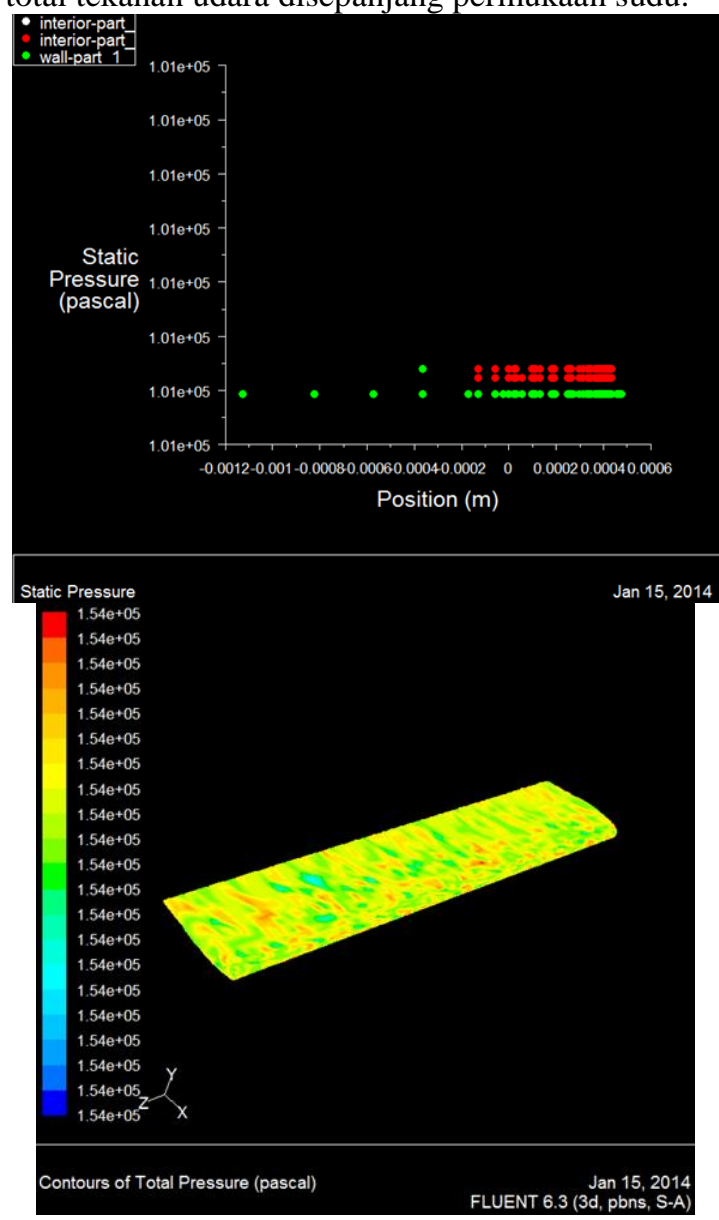

Gambar 3. Tekanan udara (aerodinamis) sepanjang permukaan sudu

Pada analisis struktur meliputi tegangan sudu, deformasi elastis sudu, dan faktor keamanan seperti ditunjukkan pada gambar dibawah. Kondisi batas saat ini pada operasi sudu memiliki putaran 20,98 rps. Besarnya beban untuk analisis ini adalah 395 , $49 \mathrm{~N}$. 


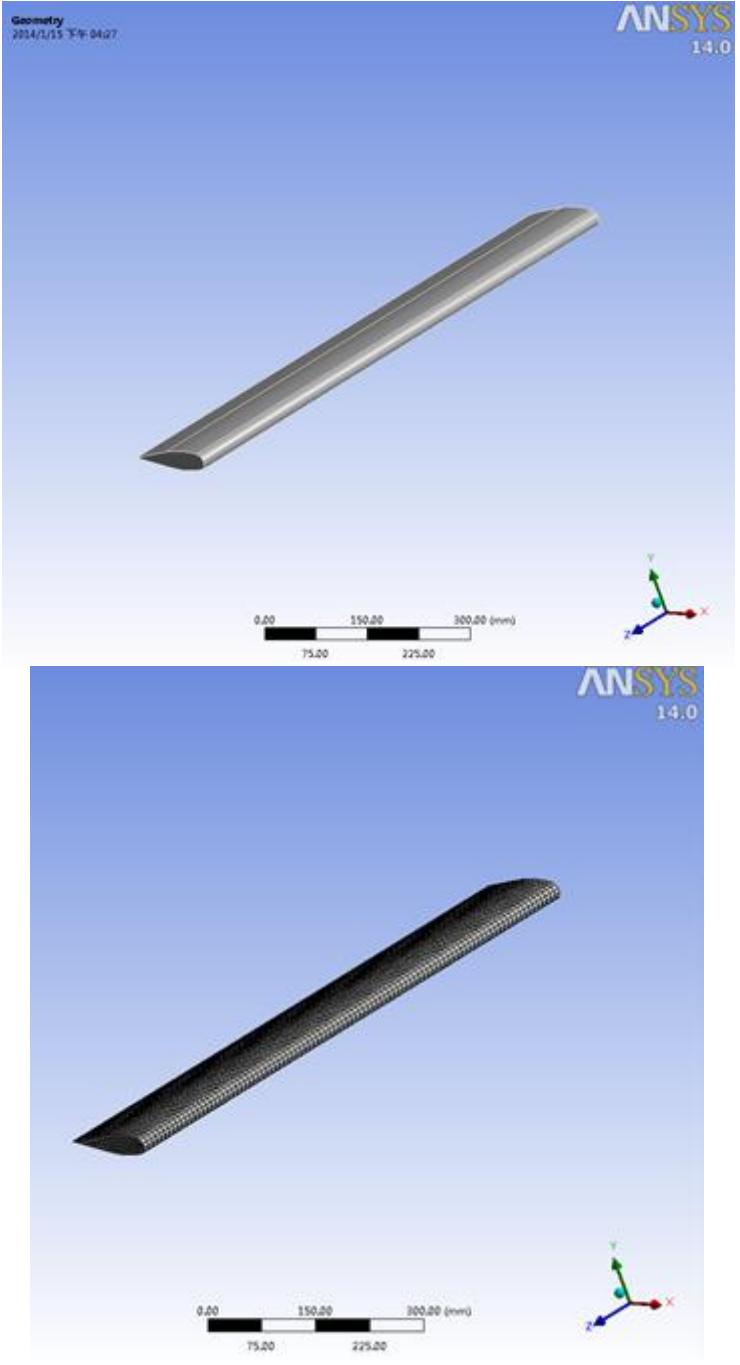

Gambar 4. Desain sudu NACA 4418 dan meshing sudu

Pengujian eksperimental, data hasil pengujian diolah untuk mendapatkan kecepatan angin, putaran poros, torsi, daya turbin, koefisien daya, tip speed ratio, dan koefisien torsi. Hasil pengolahan kemudian dipajangkan dalam bentuk grafik karakteristik turbin VAWT airfoil NACA 4418 3-sudu. Unjuk kerja masing-masing turbin tersebut dikaji dan dianalisis. Sehingga akan menghasilkan kesimpulan pada turbin dengan variasi bukaan sudut sudu (blade pitch angle), serta yang mempunyai unjuk kerja terbaik.

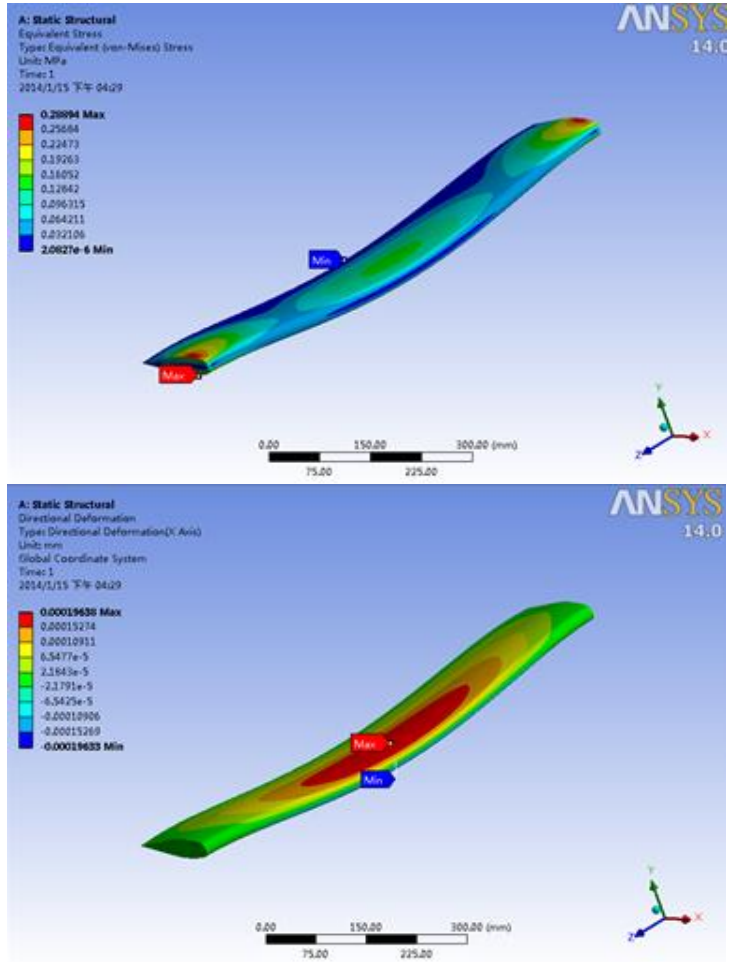

Gambar 5. Analisis struktural permukaan sudu dan faktor keamanan sudu

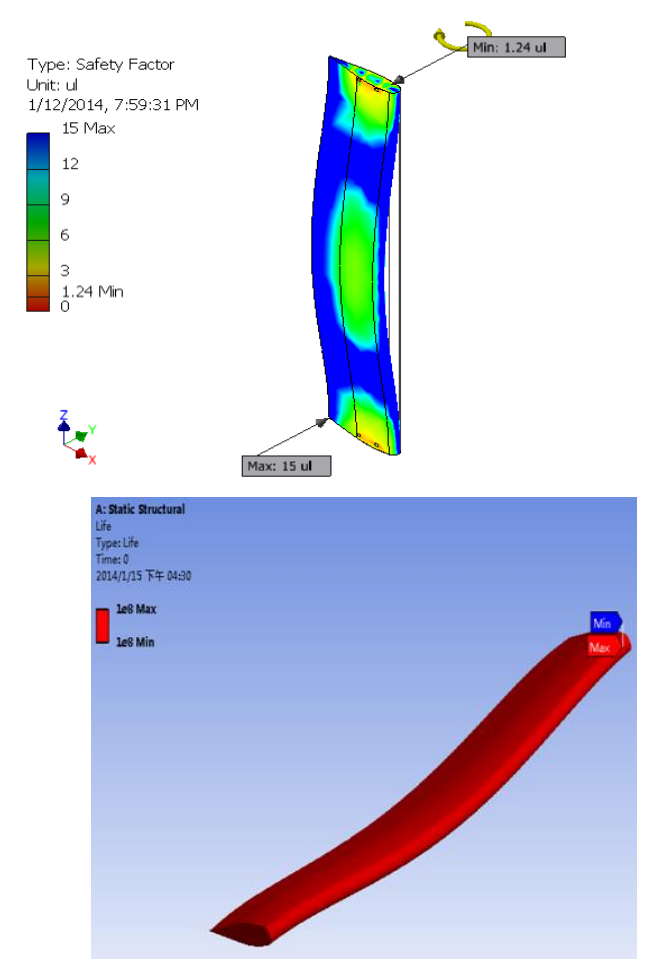

Gambar 6. Faktor keamanan sudu dan sepanjang permukaan sudu 

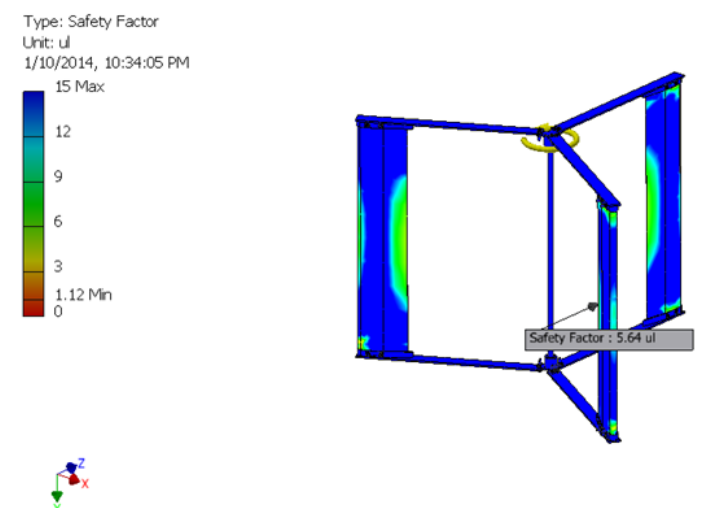

Gambar 7. Faktor keamanan sebelum pembebanan pada $v=5,42 \mathrm{~m} / \mathrm{s}$
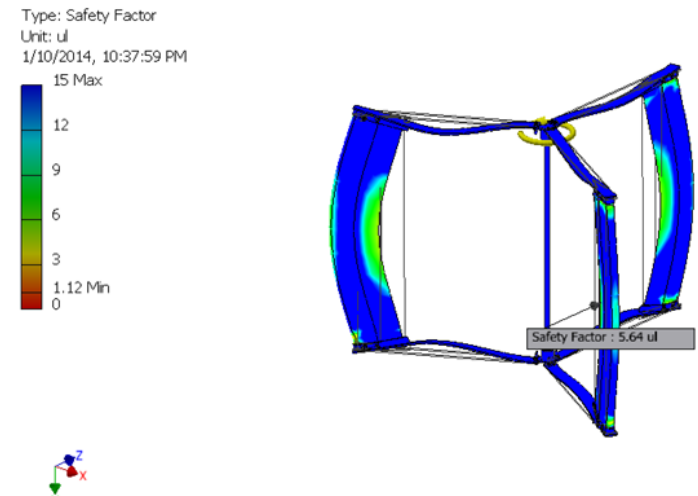

Gambar 8. Faktor keamanan sudu setelah pembebanan pada $v=5,42 \mathrm{~m} / \mathrm{s}$

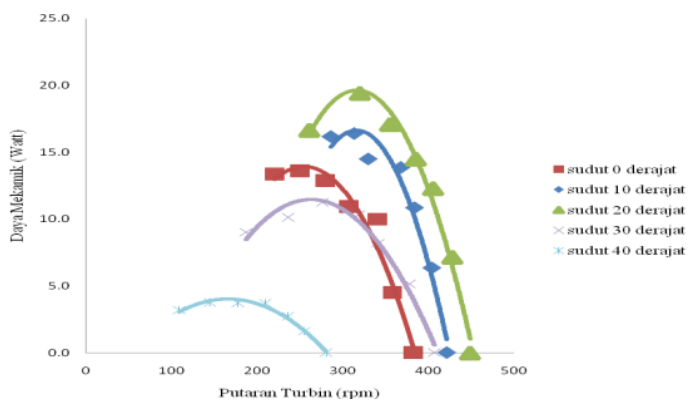

Gambar 9. Hubungan daya mekanik dengan putaran turbin pada kecepatan angin $9,2 \mathrm{~m} / \mathrm{s}$

Daya mekanik sebesar 19,4 Watt merupakan nilai optimum yang dihasilkan, terdapat pada blade pitch angle $20^{\circ}$.Sedangkan nilai dari daya minimum yang dihasikan sebesar 1,6 Watt terdapat pada blade pitch angle $40^{\circ}$.Putaran turbin tertinggi sebesar $448 \mathrm{rpm}$, terdapat pada blade pitch angle $20^{\circ}$.Apabila semakin kecil putaran turbin yang disebabkan adanya peningkatan pembebanan, maka nilai dari daya mekanik yang dihasilkan akan semakin tinggi, tetapi akan mencapai batas sehingga nilai daya mekanik akan kembali turun.

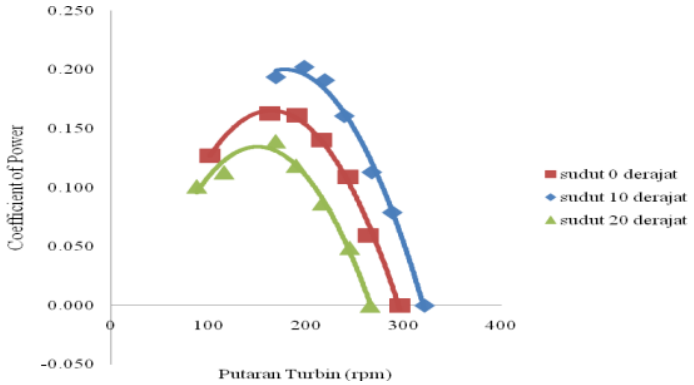

Gambar 10. Hubungan Coefficient of Power turbin dengan putaran turbin pada kecepatan angin $5,42 \mathrm{~m} / \mathrm{s}$

Pada grafik karakteristik Coefficient of Power turbin dengan putaran turbin, nilai optimum dari Coefficient of Power turbin sebesar 0,202 terdapat pada blade pitch angle $10^{\circ}$ pada putaran turbin 198 rpm dengan daya mekanik yang dihasilkan sebesar 8,5 Watt. Sedangkan nilai minimum Coefficient of Powerturbin terdapat pada blade pitch angle $20^{\circ}$ sebesar 0,049 pada putaran turbin $245 \mathrm{rpm}$ dan daya mekanik yang dihasilkan sebesar 2,1 Watt. Coefficient of Power turbin menjadi semakin tinggi dengan adanya penurunan putaran turbin yang disebabkan peningkatan pembebanan, namum apabila sudah mencapai batasnya, makanilai Coefficient of Power turbin yang dihasilkan akan kembali turun.

\section{Keunggulan Teknologi}

\section{a. Keunggulan Inovatif}

- Merupakan pendekatan teknologi menggunakan turbin VAWT sudu Aerofoil NACA 4418 skala laboratorium.

- Jika diterapkan untuk pembangkit tenaga listrik, dapat didesain dengan dimensi yang besar untuk menghasilkan daya sesuai kebutuhan.

\section{b. Keunggulan Komparatif}

- Jika diterapkan untuk pembangkit energy akan dapat menerima energy angin dari segala arah dan meningkatkan aliran udara menumbuk turbin, sehingga akan meningkatkan efisiensi dan daya turbin.

- Material yang murah dan mudah didapatkan di pasaran akan menekan biaya produksi

\section{Prospek Aplikasi}

- Penerapan rotor sudu aerofoil akan meningkatkan efisiensi dan daya turbin angin.

- Dukungan material yang murah dan mudah diperoleh dipasaran, akan menekan biaya investasi pembangunan pembangkit.

- Desain turbin untuk kecepatan angin rendah bisa diaplikasikan di seluruh wilayah Indonesia yang memiliki potensi angin diatas $3,5 \mathrm{~m} / \mathrm{s}$. 


\section{SIMPULAN}

Hasil penelitian ini menghasilkan kesimpulan :

1. Turbin angin VAWT aerofoil NACA 4418 memiliki spesifikasi sebagai berikut : diameter rotor $560 \mathrm{~mm}$, panjang sudu $800 \mathrm{~mm}$, jumlah sudu 3 buah serta bahan sudu terbuat dari fiberglass.

2. Hasil simulasi menunjukkan bahwa pembebanan struktur sudu dengan faktor keamana 5,64 ul pada kecepatan angin 5,42 $\mathrm{m} / \mathrm{s}$ akan menghasilkan tegangan optimum $185 \mathrm{MPa}$ yang diperoleh dari daya maksimum dan tegangan yang selaras dengan eksperimental.

3. Coefficient of Power (CP) optimum yang dihasilkan oleh turbin adalah 0,20 terdapat pada susut sudu $10^{\circ}$ dengan kecepatan variabel pengujian sebesar $5,42 \mathrm{~m} / \mathrm{s}$, pada putaran turbin $198 \mathrm{rpm}$, dan daya mekanik yang dihasilkan 8,5 Watt.

4. Tip Speed Rasio (TSR) yang tertinggi sebesar 1,7 terdapat pada sudut sudu $10^{\circ}$ dengan putaran turbin sebesar $321 \mathrm{rpm}$ dan kecepatan angin $5,42 \mathrm{~m} / \mathrm{s}$.

\section{UCAPAN TERIMA KASIH}

Penulis mengucapkan terimakasih kepada Politeknik Negeri Semarang yang telah membiayai pelaksanaan kegiatan Penelitian Terapan Kompetitif -PNBP dengan nomor kontrak 533/PL4.7.4.2/LT/2018.

\section{DAFTAR PUSTAKA}

1. AWEA. 2004. The American Wind Energy Association. http://www.awea.org. BWEA. 2002. The British Wind Energy Association. http://www.bwea.com. diakses tanggal 5 Oktober 2009.

2. Herlambang, Y.D., Lee, S.C., Hsu, H.C. 2017. Numerical Estimation of PhotovoltaicElectrolyzer System Performance on The Basis of a Weather Database. International Journal of Green Energy, vol. xx, pp. 1-12, 2017.

3. Herlambang, Y.D., Shyu, J.C., and Lee, S.C. 2017. A numerical study on the performance of air-breathing microfluidic fuel cells. The $12^{\text {th }}$ Annual International Conference on Nano/Micro Engineered and Molecular
Systems (NEMS), 9-12 April 2017, UCLA, California USA.

4. Herlambang, Y.D. 2017. Numerical simulation of the performance of air-breathing direct formic acid microfluidic fuel cells, IET Micro \& Nano Letters.

5. Herlambang, Y.D., Lee, S.C., and Liu, C.J. 2016. Numerical Study and Modeling of The Solar Radiation Measurement on Tilted Surface for The Local Behavior Database. 37 (5), 441-448.

6. Herlambang, Y.D., and Suwoto, G. 2010. Unjukkerja Turbin Air Mikro Aliran Silang Terhadap Variasi Sudut Sudu Jalan (Runner) Pada Debit Konstan Untuk PLTMH. Prosiding SNST Fakultas Teknik Unwahas, Semarang.

7. Beri H, and Yao Y. 2011. Effect of Chamber Airfoil on Self Starting of Vertical Axis Wind Turbine. Journal of Environment Science and Technology. Vol. 4 (3), pp. 302-312

8. Grant, A and Kelly N. 2003. The Development of a Ducted Wind Turbine Simulation Model. Eight Int. IBPSA Conference Eindhoven, Netherlands. Pp. 407-414.

9. Hau, Erich. 2006. Wind Turbines Fundamentals, Technologies, Application, Economics. $2^{\text {nd }}$ Edition. Springer-Verlag Berlin. Germany

10. Hermawan. 2010. Unjukkerja Model Turbin Angin Poros Vertikal Tipe Savonius dengan Variasi Jumlah Sudu dan Variasi Posisi Sudut Turbin. SNTTM ke-9 Palembang

11. Gupta R, Roy S, and Biswas A. 2010. Computational Fluid Dynamics of Twisted Airfoil Shaped Two Bladed H-Darrieus Rotor Made From Fibreglass Reinforced Plastic $(F R P)$. International Journal of Energy and Environment. Vol. 1. Pp. 953-968

12. Leysen E.H. 1983, Introduction to Wind Energy. PO BOX 85/Amersfort/The Netherlands: Steering Committee Wind Energy, Developing Countries

13. Soelaiman, Fauzi TA., Tandian NP., Rachmatulloh Rizki. 2010. Optimasi Penambahan Selubung (Shroud) pada Turbin Angin Sumbu Vertikal dengan Menggunakan Simulasi CFD 2 Dimensi. SNTTM ke-9 Palembang

14. Sabzevari, A. 2007. Power Augmentation in a Ducted Savonius Rotor. Pahlavy University, Iran. Second Int. Symposium Wind Energy Systems. BHRA Fluid Engineering, England 